\title{
Phase composition and microstructure of Mo-Si-V hypoeutectic alloys obtained under non-equilibrium crystallization conditions
}

\author{
(C) Alexey V. Larionov, ${ }^{*}$ Kirill V. Pikulin, ${ }^{+}$Vladimir M. Chumarev, \\ Lyudmila Y. Udoeva, and Leonid A. Smirnov \\ Laboratory of Pyrometallurgy of Nonferrous Metals. FSBIS Institute of Metallurgy. \\ Ural Branch of RAS. Amundsen St., 101. Yekaterinburg, 620016. Sverdlovsk Region. Russia. \\ Phone: +7 (343) 232-90-24. E-mail:pikulin.imet@gmail.com
}

\begin{abstract}
*Supervising author; ${ }^{+}$Corresponding author
Keywords: Mo-Si alloy, hypoeutectic composition, vanadium, doping, phase formation, microstructure, microhardness.
\end{abstract}

\section{Abstract}

The phase composition, microstructure are investigated and the densities of Mo-15.3Si (at. \%) hypoeutectic alloys alloyed with vanadium are determined. The main phase components of the alloys and their volumetric contents were determined by X-ray phase analysis (XRD) and X-ray microanalysis (RSMA) methods. The unit cell parameters of the main phases of Mo-Si-V alloys are calculated. It is shown that with the introduction of up to 20.0 at. \% of vanadium into the hypoeutectic alloy Mo-15.3Si, a structure is formed consisting of two solid solutions: $(\mathrm{Mo}, \mathrm{V})_{\mathrm{ss}}$ with silicon dissolved in it (up to 5.0 at. \%) and $(\mathrm{Mo}, \mathrm{V})_{3} \mathrm{Si}$ with a silicon deficiency of about 4.0 at. \% trelative to the stoichiometric composition. With an increase in the content of vanadium in alloys, the volume ratio of the metal component to the silicide ratio almost doubles. At the same time, the microhardness of the metal phase increases 1.5 times and reaches $887 \mathrm{HV}$, and the microhardness of silicide, on the contrary, decreases by 1.2 times and is $1057 \mathrm{HV}$. The dependences of the microhardness of the structural components of the alloys, as well as the parameters of their crystal lattices on the concentration of the alloying element in them, are consistent with the concepts of the formation of substitution solid solutions, both in the metal and in the silicide phases. The introduction of 20.0 at. \% of vanadium into the Mo-15.3Si hypoeutectic alloy reduces its density, and, therefore, the mass of the alloy by $10.5 \%$ from 9.49 to $8.49 \mathrm{~g} / \mathrm{cm}^{3}$.

\section{References}

[1] B.P. Bewlay, M.R. Jackson, J.C. Zhao, P.R. Subramaniam. A review of very-high-temperature Nb silicide-based composites. Metallurgical and Materials Transactions A. 2003. 34A. P.2043-2052.

[2] I.L. Svetlov. High-temperature Nb-Si-composites. Material Science. 2010. No.9. P.29-38. (russian)

[3] D.V. Grashchenko, B.V. Shchetanov, I.Yu. Efimochkin. The development of powder metallurgy of heatresistant materials. All materials. Encyclopedic reference. 2011. No.6. P.10-22. (russian)

[4] A.K. Vasudevan, J. Petrovic. A comparative overview of molibdenium disilicide composites. Materials Science and Engineering. 1992. Vol.A155. P.1-17.

[5] M.H. Hebsur. Development and characterization of $\mathrm{SiC} / \mathrm{MoSi}_{2}-\mathrm{Si}_{3} \mathrm{~N}_{4}$ hybrid composites. Materials Science and Engineering. 1999. Vol.A261. P.24-37.

[6] M. Mousa, N. Wanderka, M. Timpel. Modification of Mo-Si alloy microstructure by small additions of Zr. Ultramicroscopy. 2011. Vol.111. No.6. P.706-710.

[7] M. Esmaeili Ghayoumabadi, A. Saidi, M.H. Abbasi. Lattice variations and phase evolutions during combustion reactions in Mo-Si-Al system. Journal of Alloys and Compounds. 2009. Vol.472. No.1-2. P.84-90.

[8] I. Rosales, J.H. Schneibel. Stoichiometry and mechanical properties of $\mathrm{Mo}_{3} \mathrm{Si}$. Intermetallics. 2000 . №8. P.885-889.

[9] A.V. Larionov, L.Y. Udoeva, V.M. Chumarev, and A.N. Mansurova. Thermodynamic simulation of phase formation in the Mo-Si alloys doped with yttrium. Butlerov Communications. 2015. Vol.43. No.9. P.84-88. DOI: 10.37952/ROI-jbc-01/15-43-9-84

[10] A.V. Larionov, L.Y. Udoeva, and V.M. Chumarev. Thermodynamic simulation of phase formation in the Mo-Si, alloys doped with scandium or neodymium. Butlerov Communications. 2015. Vol.43. No.9. P.89-96. DOI: 10.37952/ROI-jbc-01/15-43-9-89 
[11] A.N. Mansurova, A.V. Larionov, S.N. Tyushnyakov, and L.A. Marshuk. Phase composition and microstructure of the obtained under nonequilibrium crystallization conditions Mo-Si alloys. Butlerov Communications. 2015. Vol.43. No.9. P.97-101. DOI: 10.37952/ROI-jbc-01/15-43-9-97

[12] L.Yu. Udoeva, A.V. Larionov, V.M. Chumarev, A.N. Mansurova, and S.N. Tushnyakov. The phase formation study of the hypoeutectic Mo-Si alloys, doped with REM (Sc, Y, Nd). Butlerov Communications. 2016. Vol.47. No.8. P.106 114. DOI: 10.37952/ROI-jbc-01/16-47-8-106

[13] L.Yu. Udoeva, V.M. Chumarev, A.V. Larionov, S.V. Zhidovinova, S.N. Tyushnyakov. Influence of rare-earth elements on the structural phase state in situ of Mo-Si-X composites (X $=\mathrm{Sc}, \mathrm{Y}, \mathrm{Nd})$. Perspective materials. 2017. No.7. P.24-33. (russian)

[14] E.N. Kablov, O.G. Ospennikova, A.V. Vershkov. Rare metals and rare earth elements are materials of modern and high technologies of the future. Proceedings of VIAM. 2013. No.2. P.1-11. (russian)

[15] L.A. Smirnov, V.A. Rovnushkin, A.S. Oryschenko. Modification of steel and alloys with rare-earth elements. Metallurgist. 2015. No.11. P.50. (Message 1) (russian)

[16] E.M. Savitsky, V.V. Baron, Yu.V. Efimov, E.I. Gladyshevsky. Investigation of the vanadiummolybdenum-silicon system. Journal of Inorganic Chemistry. 1962. Vol.7. No.5. P.1117-1125. (russian)

[17] E.M. Savitsky, V.V. Baron, Yu.V. Efimov, E.I. Gladyshevsky. The solubility of some transition metals in the compound $\mathrm{V}_{3} \mathrm{Si}$ and their effect on the transition temperature of the compound to the superconducting state. Inorganic materials. 1965. Vol.1. No.3. P.354-361. (russian)

[18] D. Yi, C. Li, Z. Lai. Ternary alloying study of $\mathrm{MoSi}_{2}$. Metallurgical and Materials Transactions A. 1998. Vol.29A. P.119-129.

[19] T. Fukui, S. Ueno, R. Tanaka. Effect of niobium or vanadium addition on the microstructure and hardness of $\mathrm{MoSi}_{2}-\mathrm{Mo}_{5} \mathrm{Si}_{3}$ eutectic alloys. Journal of the Japan Institute of Metals and Materials. 1999. Vol.63. No.5. P.613-616.

[20] F.-G. Wei, Y. Kimura, Y. Mishima. Microstucture and phase stability in $\mathrm{MoSi}_{2}-\mathrm{TSi}{ }_{2}(\mathrm{~T}=\mathrm{Cr}, \mathrm{V}, \mathrm{Nb}, \mathrm{Ta}$, Ti) pseudo-binary systems. Material Transactions JIM. 2001. Vol.42. No.7. P.1349-1355.

[21] F. Maglia, C. Milanese, U. Anselmi-Tamburini, Z.A. Munir. Self-propagating high-temperature synthesis microalloying of $\mathrm{MoSi}_{2}$ with $\mathrm{Nb}$ and V. Journal of Materials Research. 2003. Vol.18. No.8. P.1842-1848.

[22] C.J. Rawn, J.H. Schneibel, C.L. Fu. Thermal expansion anisotropy and site occupation of the pseudobinary molybdenum vanadium silicide $\mathrm{Mo}_{5} \mathrm{Si}_{3}-\mathrm{V}_{5} \mathrm{Si}_{3}$. Acta Materialia. 2005. Vol.53. P.2431-2437.

[23] H. Nowotny, R. Machenschalk, R. Kieffer, F. Benesovsky. Investigation of the silicides systems (in German). Monatsh. Chem. 1954. No.85. P.241-244.

[24] F. Benesovsky, E. Rudy. Untersuchungen im system V-Mo-C. Stabilisierung des kubischen molybdaenkarbids. Planseeber. Pulvermetall. 1962. No.10. P.42.

[25] Powder Diffraction File (PDF), produced by the International Centre for Diffraction Data, Newtown Square, PA. 2014. 